\title{
EFFECT OF EMPLOYEE WORK EFFECTIVENESS ON SERVICE EFFICIENCY IN THE NORTH BUNGKU SUB-DISTRICT OFFICE IN NORTH MOROWALI DISTRICT
}

\author{
Kisman Karinda ${ }^{\mathbf{a}}$, La Ode Sabirila Jayalangi ${ }^{\mathbf{b}}$ \\ ${ }^{a}$ Government Science Study Program, Faculty of Social Sciences, Political Sciences, \\ Muhammadiyah University of Luwuk, Email: kisman@unismuhluwuk.ac.id \\ ${ }^{b}$ Government Science Study Program, Faculty of Social Sciences, Political Sciences, \\ Muhammadiyah University of Luwuk, Email: laodesabirila38@gmail.com
}

\begin{abstract}
This study aims to examine and analyze the magnitude of the Effect of Employee Work Effectiveness on Service Efficiency in the North Bungku Sub-District Office in North Morowali district. Research design uses quantitative design. Data collection methods used in this study are documentation, interviews with employees and questionnaires distributed to 24 people. The analytical tool used in this study is the analysis of Simple Linear Regression Analysis using the SPSS version 16.0 program. The results showed that there was a significant effect of Employee Work Effectiveness Variables (X) partially on the Service Efficiency in the North Bungku sub-District Office (Y). This can be seen from the value of the regression coefficient $=1.359$, and the significant level> 0.001 with obtained tcount $=3.808$ greater than $\mathrm{t}$ table $=1.876$ at the 0.05 significance level which means accepting $\mathrm{Ha}$ and rejecting Ho. There is a significant effect of Employee Work Effectiveness Variables (X) simultaneously on Service Efficiency (Y). From the test results of the F test obtained Fcount $=14.499$ greater than Ftable $=4.301$ and the value of the Coefficient of Determination (R2) value 0.397 which means 39.7\% Service Efficiency in North Bungku District Office North Morowali Regency is influenced by Employee Work Effectiveness while $60.3 \%$ influenced by other factors outside of Employee Work Effectiveness
\end{abstract}

Keywords: Employee Work Effectiveness, Service Efficiency 
Proceeding ICOGISS 2019

Page:455-465 ISBN: 978-602-6 988-75-1

Web Jurnal Online: jurnal.unmuhjember.ac.id

By: Kisman Karinda; La Ode Sabirila Jayalangi

Effect Of Employee Work Effectiveness On Service Efficiency In The North Bungku

Sub-District Office In North Morowali District

\section{INTRODUCTION}

Human resources (HR) are the main elements or central factors in an organization whatever the form of the organization. Are these organizations profit organizations (companies and industries), non-profit organizations (government agencies and community organizations). Thus HR, namely employees or employees of an organization including the Bungku Utara District organization must be managed effectively and efficiently to become an effective and efficient Subdistrict in achieving its objectives. Managing or managing HR professionally will be able to create an effective organization.

Work effectiveness consists of two words, namely effectiveness and work. As said by Richard M. Steers, a job is said to be effective if a job can be completed on time in accordance with a predetermined plan. (in Steers, 1985: 46-48). Work effectiveness shows the ability of an organization to achieve goals that have been set precisely, in accordance with the target time with the size and standard that applies. Achieving these objectives shows that the organization has worked effectively and is able to continue to live.

In fact, Sub-district employees are the most important influence factor because their behavior will facilitate or hinder the achievement of the Kecamatan objectives. Subdistrict employees are resources that are directly related to the management of all existing resources in the Sub-District, especially in providing community services in order to meet the needs and desires of the Sub-District community as service users.

Bungku Utara sub-District employees are the main capital in the sub-district which will have a big influence on effectiveness, because even though the technology used is a sophisticated technology and is supported by a good structure, without any employees it is of no use.

The effectiveness of the employees of Bungku Utara sub-District in public service practices can be assessed by using measuring instruments in the form of questions such as: do employees of Bungku Utara sub-District have the ability to adjust to the demands of a growing community? What are the work performance of the Bungku Utara subDistrict staff? Have the community been satisfied with the provision of services by employees of Bungku Utara sub-District? Of all the measuring instruments used to take pictures of community service delivery in Bungku Utara sub-District, there is a tendency that the service delivery has not been maximized so that the work effectiveness of Bungku Utara sub-District staff can not be effective and can lead to negative image and mistrust of residents of Bungku Utara sub-District staff.

A successful organization is an organization that is able to create together a high level of efficiency and effectiveness. Efficiency shows the ability of the organization to use resources properly and there is no waste, and conversely the effectiveness shows the ability of an organization to achieve goals that have been set precisely, so that between effectiveness and efficiency are interrelated. Organizations are not only required to pursue purely goals, but how they can be achieved efficiently.

The efficiency of public services can be interpreted as a comparison between input and output. The input intended here can be in the form of costs, time and energy. In terms of input, public services are said to be efficient if the service uses cheap and not wasteful 
resources. In terms of the process, so that it can be said to be efficient, public service procedures must be simple so that citizens do not spend a lot of energy and costs in accessing a service. While from the output side, public services are said to be efficient if the use of cheap and non-wasteful resources earlier produces service products that are in accordance with the standards and satisfy service users.

Efficiency in public services can be seen from the perspective of service providers and service users. From the perspective of service providers, service providers must strive for low service prices and no waste of public resources. Public services should involve as few employees as possible and be given in a short time. Likewise, from the perspective of service users, they want public services to be achieved at a low cost, short time, and not waste much energy.

According to the researchers' initial observations that service efficiency was not maximal. This is probably due to the low work effectiveness of the Bungku Utara subdistrict staff, such as in making and renewing ID cards, building permits, business licenses, land certification, birth certificates and multiple retributions withdrawn from residents so that all costs incurred by residents users to be given to employees of the subDistrict of Bungku Utara so that they can be served quickly and not verbally. This causes the price of public services to be more expensive in terms of the price provisions or even free. These additional costs are often interpreted by employees of Bungku Utara subDistrict as a thank you for the service they have provided. This phenomenon has spread in the era of regional autonomy because each region has a tendency to try to increase PAD (local revenue) by collecting funds from the public.

Based on the background above, the purpose of this study is to examine and analyze the magnitude of the Effect of Employee Work Effectiveness on Service Efficiency in the North Bungku Sub-District Office in North Morowali district.

\section{Literature Review}

a. Definition of Effectiveness

Understanding effectiveness according to Sedarmayanti in his book entitled Human Resources and Work Productivity that::

Effectiveness is a measure that gives an idea of how far the target can be achieved.

The definition of effectiveness is more output-oriented while the problem of using input is not a major concern. If efficiency is associated with effectiveness, even if there is an increase in effectiveness, efficiency may not necessarily increase. (Sedarmayanti, 2009: 59).

Based on the above understanding, that something can work in accordance with what is expected correctly and successfully, then something is already running effectively and efficiently, meaning that information must be in accordance with the needs of the community. The purpose of government can be achieved if every government agency needs to carry out its activities more effectively and efficiently so that the goals set can be achieved.Sondang P Siagian (Samba, 2009: 31) reveals several things that become criteria in measuring effectiveness: Effectiveness can be measured from a variety of things, namely: clarity of goals to be achieved, clarity of strategies to achieve goals, process 
analysis and formulation of policies that are solid, careful planning, proper programming, availability of work facilities and infrastructure, effective and efficient implementation, system educating and controlling.

From the various theories above, According to Steers, 1985: 46-48) states that what is meant by employee work effectiveness is the ability of employees to display their performance quality appropriately which is characterized by using several criteria namely:

- Outcomes in the sense that what is given or done is really in accordance with what is needed,

- Responsibility in the sense of one's obligation to carry out the functions assigned as well as possible according to the direction received,

- Objectives in the sense of achieving agreed targets for joint ventures,

- Motivation in the sense that there is a force of encouragement that emerges from each individual to achieve goals, and

- Spirit in the sense of feeling bound in terms of achieving goals, which involves additional effort, togetherness of purpose and feeling of belonging.

b. Definition of Efficiency

Kermally (1996: 69) said that: "Efficiency is doing the right thing where effectiveness is doing the right thing right". (Efficiency is doing things right, while effectiveness is doing something right).

Based on the theories described above, According to Kermally (1996: 69) states that what is meant by public service efficiency is the ability to minimize the use of power resources correctly and precisely in fulfilling the desires and needs of the community, with several indicators namely:

- Savings in the sense that people get what they want at a low cost,

- True in the sense that employees provide services in accordance with the applicable rules and according to their respective duties and functions.

- Timely in the sense that what is given or done is really in accordance with the time specified,

- Needs in terms of employee responsiveness in helping and providing services to customers quickly,

- Satisfaction in the sense of a condition that is felt by all people in receiving services according to what they want.

\section{RESEARCH METHODS}

a. Research Sites

This research was conducted in Bungku Utara sub-District North Morowali Regency. The time needed from the implementation of observations to the process of completing research activities requires approximately three (3) months, from September to November 2017.

b. Population and Research Samples

- Research population. Population is a generalization area consisting of objects / subjects that have certain qualities and characteristics that are determined by 
researchers to be studied and conclusions drawn later (Sugiono, 2004: 90). In this study the population is all employees of the Bungku Utara sub-District Office, with a population of 24 people.

- Research Samples. Samples are part of the number and characteristics of the population. (Sugiono, 2005: 96). According to Arikunto (1991: 107) if the subject or polpulation is less than 100 people, it is better to take everything so that the research is a population research. The sample in this study were all Structure and Staff employees at the Bungku Utara sub-District Office, which were 24 people.

c. Data Collection Methods

In an effort to collect accurate data about the variables to be studied, the researchers used several techniques as follows:

- Documentation Method. The documentation method is to find data on things or variations in the form of notes, transcripts, books, newspapers, magazines, inscriptions, minutes of meetings, agendas and so on (Arikunto, 2002: 134).

- Documentation is used to obtain preliminary data and accurate information about variables investigated in relation to the efficiency of public services and the effectiveness of employee work.

- Interview Method. Data collection techniques with interviews are data collection techniques by asking directly to data sources or face to face with employees of Bungku Utara District Office to find out about the Effect of Employee Work Effectiveness on Service Efficiency in Bungku Utara sub-District, North Morowali Regency. This interview was conducted to obtain the information needed. In this study, research instruments in the form of interview guidelines are needed, by first preparing and determining the questions that will be asked to get clarity from the problem.

- Questionnaire Method (Questionnaire). A questionnaire is a number of written questions that are used to obtain information from the respondent in the sense of reports about his personality or things he knows (Arikunto, 2002: 139). Questionnaires are used to obtain data concerning the work effectiveness of employees, and the efficiency of public services at the Bungku Utara District Office. This questionnaire was given to 24 people.

d. Data Analysis Techniques

The data analysis technique used by the author is quantitative data analysis techniques, namely Analysis to determine the Effect of Employee Work Effectiveness on Service Efficiency in the North Bungku Sub-District Office North Morowali district, namely by using the following instruments:

- Simple Linear Regression Analysis.

This analysis is to determine the effect of a performance variable associated with organizational culture variables (Djarwanto and Subagyo: 1996).

$\mathrm{Y}=\mathrm{a}+\mathrm{bX}+\epsilon$

Where:

$\mathrm{Y}=$ Service Efficiency

$\mathrm{a}=$ Constant 
$\mathrm{X}=$ Employee Work Effectiveness

$\mathrm{b}=$ regression coefficient which is the amount of change that occurs in $\mathrm{Y}$ if one unit changes in the independent variable (variable $\mathrm{x}$ )

$\epsilon=$ Prediction error

Statistical analysis was carried out with the help of SPSS Version 16.0 software

- Pearson Product Moment Correlation Analysis

This method is used to determine the presence or absence and the size of the relationship between Employee Work Effectiveness on Service Efficiency, then use the formula as follows: (Sugiono, 2004: 212).

$$
\text { Rumus : } r[?][?][?][?][?][?]=\frac{n(\Sigma x y)-(\Sigma x)(\Sigma y)}{\sqrt{\{(n . \Sigma x[?][?]-(\Sigma x)[?][?]\} \cdot\{n \cdot \Sigma y[?][?]-(\Sigma y)[?] ?]\}}}
$$

Information :

$\mathbf{r}_{x y}=$ Pearson Product Moment Correlation Index Number

$\mathrm{N}=$ Sample size

$\Sigma \mathrm{xy}=$ Amount of product multiplication between score $\mathrm{X}$ and score $\mathrm{Y}$

$\Sigma \mathrm{x}=$ Total score $\mathrm{X}$

$\Sigma \mathrm{y}=$ Amount of all Y scores

Statistical analysis was carried out with the help of SPSS Version 16.0 software Interpretation of these correlations according to conservative measures is as follows:

Table 1. Guidelines for providing coefficient interpretation

\begin{tabular}{|c|c|}
\hline Coefficient Interval & Relationship Level \\
\hline $0,00-0,19$ & Very low \\
\hline $0,20-0,39$ & Low \\
\hline $0,40-0,59$ & High enough \\
\hline $0,60-0,79$ & High \\
\hline $0,80-1,00$ & Very high \\
\hline
\end{tabular}

With the $\mathrm{r}$ value obtained, we can see directly through the correlation table to test whether the $r$ value we get has a influence or not. The table lists certain significant $r$ boundaries, in this case a significant $5 \%$ if the $r$ value is significant, meaning the alternative hypothesis can be accepted.

- Determinant coefficient

The coefficient of determination is used to find out how much (percentage) the effect caused by the independent variable on the dependent variable.

The formula used is as follows: 
Page:455-465 ISBN: 978-602-6 988-75-1

Web Jurnal Online: jurnal.unmuhjember.ac.id

By: Kisman Karinda; La Ode Sabirila Jayalangi

Effect Of Employee Work Effectiveness On Service Efficiency In The North Bungku

Sub-District Office In North Morowali District

$$
\mathrm{D}=\left(\mathrm{r}^{2}\right) \times 100 \%
$$

Information :

D : The coefficient of determination

$r$ : Product moment correlation coefficient (Sugiono, 2004: 149).

Statistical analysis was carried out with the help of SPSS Version 16.0 software.

\section{RESULTS AND DISCUSSION}

a. The Effect of partially Employee Work Effectiveness on Service Efficiency in the Sub-District Office of Bungku Utara.

The null hypothesis (Ho) states that the work effectiveness of employees does not affect service efficiency while on the other hand the alternative hypothesis (H1) states that employee work effectiveness affects service efficiency.

Based on the research obtained the results of the calculation of Regression Analysis using the SPSS for Windows 16.0 Computer Program as follows:

Table 2. Test $t_{\text {hitung }}($ Coefficients(a) ).

\begin{tabular}{|c|c|c|c|c|c|c|}
\hline Model & & $\begin{array}{c}\text { Unstandardized } \\
\text { Coefficients }\end{array}$ & & $\begin{array}{c}\text { Standardized } \\
\text { Coefficients }\end{array}$ & $\mathrm{t}$ & Sig. \\
\hline & & B & $\begin{array}{l}\text { Std. } \\
\text { Error }\end{array}$ & Beta & & \\
\hline \multirow[t]{2}{*}{1} & |(Constant) & -36.961 & 26.109 & & $\begin{array}{r}- \\
1.416\end{array}$ & .171 \\
\hline & $\begin{array}{l}\text { EFFECTIVENESS } \\
\text { OF EMPLOYEE'S } \\
\text { WORK }\end{array}$ & 1.359 & .357 & .630 & 3.808 & .001 \\
\hline $\begin{array}{l}\text { a. Dependent } \\
\text { Variable: } \\
\text { EFFICIENCY } \\
\text { OF SERVICE }\end{array}$ & & & & & & \\
\hline
\end{tabular}

Based on the following table a simple linear regression equation is obtained as follows: $\mathrm{Y}=-36,961+(1,359) \mathrm{X}$. The regression equation has the meaning:

- Constant $-36,961$, this means that if the employee work effectiveness variable $=$ 0 , then the service efficiency is $-36,961$.

- Coefficient $=1,359$, meaning if the variable work effectiveness of employees has increased by 1 (one) point, it will affect service efficiency by 1,359 points.

In Table 2. The count test (Coefficients (a)) above obtained a regression coefficient for Employee Work Effectiveness variable is 1.359 which in its significance test with $\mathrm{t}$ test obtained tcount $=3.808$ greater than $t$ table $=1.876$ at the real level of 0.05 can be said that there is a positive relationship between Effectiveness Employee Work (X1) with 
Proceeding ICOGISS 2019

Page:455-465 ISBN: 978-602-6 988-75-1

Web Jurnal Online: jurnal.unmuhjember.ac.id

By: Kisman Karinda; La Ode Sabirila Jayalangi

Effect Of Employee Work Effectiveness On Service Efficiency In The North Bungku

Sub-District Office In North Morowali District

Service Efficiency (Y) is very significant. In other words, Employee Work Effectiveness affects Service Efficiency. With a significant level of 0.001 (a)

b. The Effect of Simultaneous Employee Work Effectiveness on Service Efficiency in the Sub-District Office of Bungku Utara.

The null hypothesis (Ho) states that Employee Work Effectiveness does not affect Efficiency While on the other hand the alternative hypothesis (H1) states that Employee Work Effectiveness increases Service Efficiency.

Based on research obtained from the results of Regression Analysis using the SPSS Computer Program for Windows 16.0 as follows:

Table 3. Test $\mathrm{F}_{\text {hitung }}$ (ANOVA)

\begin{tabular}{|l|l|r|r|r|r|r|}
\hline Model & & $\begin{array}{c}\text { Sum of } \\
\text { Squares }\end{array}$ & $\begin{array}{c}\text { Mean } \\
\text { Square }\end{array}$ & F & Sig. \\
\hline 1 & Regression & 185.844 & 1 & 185.844 & 14.499 & $.001^{\mathrm{a}}$ \\
\hline & Residual & 281.989 & 22 & 12.818 & & \\
\hline & Total & 467.833 & 23 & & & \\
\hline $\begin{array}{l}\text { a. Predictors: (Constant), } \\
\text { WFECTIVENESS OF EMPLOYEE'S }\end{array}$ & & & & & & \\
\hline $\begin{array}{l}\text { W. Dependent Variable: EFFICIENCY } \\
\text { OF SERVICE }\end{array}$ & & & & & & \\
\hline
\end{tabular}

Based on the table above, the results of the $t$ test are obtained Fcount $=14.499$ with a significant value of 0.001 (a) because the price is significant $<0.05$, indicating that the calculated $F$ value is very significant. Thus showing that together Employee Work Effectiveness (X) has an effect on Service Efficiency.

Furthermore, the coefficient of determination $\left(\mathrm{R}^{2}\right)$ is used to measure how far the ability of the model in explaining variations in the dependent variable. The calculation of the determination coefficient (R2) can be seen from the following table using the SPSS 16.0 for Windows computer program :

Table 4. Determination Coefficient Test Results (Model Summary(b))

\begin{tabular}{|l|l|r|r|r|r|r|r|r|r|}
\hline Model & & $\mathrm{R}$ & Adjusted & $\begin{array}{c}\text { Std. } \\
\text { Error of } \\
\text { the } \\
\text { Estimate }\end{array}$ & $\begin{array}{c}\text { Statistics } \\
\text { Change }\end{array}$ & & & & \\
\hline & & & & & $\begin{array}{c}\text { R Square } \\
\text { Change }\end{array}$ & $\begin{array}{c}\text { F } \\
\text { Change }\end{array}$ & df1 & df2 & $\begin{array}{c}\text { Sig. F } \\
\text { Change }\end{array}$ \\
\hline 1 & & & & & & & & & \\
\hline a. Predictors: & & & & & & & & \\
\hline
\end{tabular}




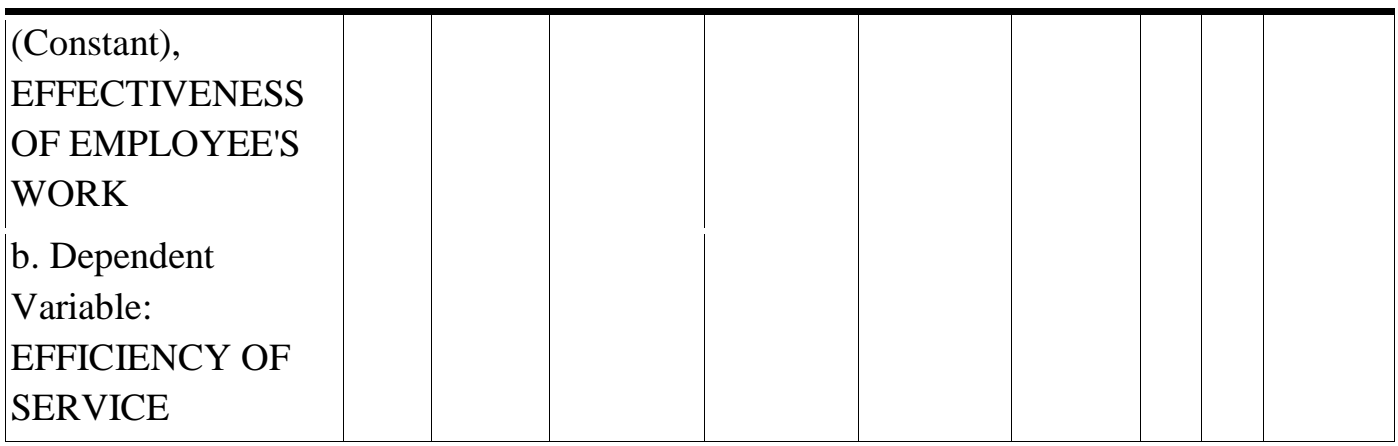

From the results of these calculations obtained a value of $R=0.630$ (a) and $R 2$ value of 0.397 which means $63 \%$ Service Efficiency in the office of North Bungku Sub-District is influenced by Employee Work Effectiveness while 37\% is influenced by other factors beyond Employee Work Effectiveness. With a significant level of 0.001 (a).

\section{CONCLUSION}

a. Conclusions.

Based on the results of research, data analysis and the results of studies in previous chapters the authors can conclude the following matters:

- There is a significant effect of Employee Work Effectiveness Variables (X) partially on the Service Efficiency in Bungku Utara Sub-District Office (Y). This can be seen from the regression coefficient $=1.359$, and the significant level> 0.001 by obtaining tcount $=3.808$ greater than $\mathrm{t}$ table $=1.876$ at the 0.05 significance level which means accepting $\mathrm{Ha}$ and rejecting Ho

- There is a significant effect of Employee Work Effectiveness Variables (X) simultaneously on Service Efficiency in the Bungku Utara Sub-District Office (Y). From the results of testing the $\mathrm{F}$ test obtained Fcount $=14.499$ greater than Ftable $=4.301$ and the value of the Coefficient of Determination (R2) value 0.397 which means $39.7 \%$ Service Efficiency in the Office of North Bungku District is influenced by Employee Work Effectiveness while 60.3\% is influenced by other factors Beyond the Effectiveness of Employee Work.

b. Suggestions.

Based on the conclusions above, the author can suggest the following:

- Leaders must motivate their employees to do their jobs as well as possible and also leaders must improve the reliability of employees in serving the community by always supervising subordinates.

- Sub-district employees must be responsible for the quality of the implementation of public services and the results of their work to be effective. 
Proceeding ICOGISS 2019

Page:455-465 ISBN: 978-602-6 988-75-1

Web Jurnal Online: jurnal.unmuhjember.ac.id

By: Kisman Karinda; La Ode Sabirila Jayalangi

Effect Of Employee Work Effectiveness On Service Efficiency In The North Bungku

Sub-District Office In North Morowali District

\section{REFERENCES}

Arikunto, Suhartini. 1991. Prosedur Penelitian Suatu Pendekatan Praktik. Bina Aksara, Jakarta

Jakarta

Basrowi dan Suwandi. 1996. "Memahami Penelitian Kualitatif. Jakarta : Rineka Cipta.

Boediono, B. 2003. Pelayanan Prima perpajakan. Jakarta : PT. Rineka Cipta.

Badudu Zain, Kamus Umum Bahasa Indonesia,Jakarta: Pustaka Sinar Harapan.

Budiman, Arief. 1997. Teori Negara. Jakarta: Pt. Gramedia Pustaka Utama.

Kaloh, J. 2002. Corporate Culture And Performance. New York: The Free Press.

Kartini Kartono 2006. Kepemimpinan Dan Prilaku Organisasi. Jakarta: Pt Raja Grafindo Persada.

Kermally, Sultan 1996. Total Management Thinking. Great Britain: Biddles Ltd, Guildford And King's Lynn.

Kotler Philip. 2008. Marketing Managemet The Millenium Edition. Ten Edition. USA: Prentice- Hall, Inc

Mahsun, Mohammad 2006. Pengukuran Kinerja Sektor Publik, Yogyakarta :Bpfe Yogyakarta 2006.

Maskun, Sumitro. 2002. Profesi Aparatur Negara dalam Birokrasi Indonesia. Makalah disajikan pada Seminar Nasional Ilmu-Ilmu Sosial. Medan.

Moenir H.A.S 2000.Manajemen Pelayanan Umum Di Indonesia. Jakarta : Pt.Bumi Aksara.

Nawawi, Hadari, 2007, Metode Penelitian Sosial, Gajah Mada University Press.

Poerwadarminta, WJS. 2005. Kamus Umum Bahasa Indonesia. PN Balai Pustaka. Jakarta

Rasyid, Mohammad Ryaas, 1999. Kajian Awal Birokrasi Pemerintahan Dan Politik Orde Baru. Jakarta: Yasrif, Watampone.

Rivai, Veithzal 2008. Kepemimpinan F Dalam Sikap Perilaku Organisasi ,Jakarta. Pt.Raja Grafindo Persada.

Rothwell, William J. 1992. Mastering Instructional Design Process: A Systematic Approach. San Francisco: Jossey Bass Publisher.

Sedarmayanti. 2009. Good Governance (Kepemimpinan Yang Baik) Bagian Kedua: Membangun Sistem Manajemen Kinerja Guna Meningkatkan Produktivitas Menuju Good Governance (Kepemimpinan Yang Baik). Bandung: Mandar Maju. 
Proceeding ICOGISS 2019

Page:455-465 ISBN: 978-602-6 988-75-1

Web Jurnal Online: jurnal.unmuhjember.ac.id

By: Kisman Karinda; La Ode Sabirila Jayalangi

Effect Of Employee Work Effectiveness On Service Efficiency In The North Bungku

Sub-District Office In North Morowali District

Sugiyono, 2006, Statistika untuk Penelitian, Bandung : Alfabeta

Soedarjat 1993. Kapita Selekta Manajemen Dan Kepemimpinan Serta Imlementasinya.Jakarta : Ind Hill Co.

Stoner, James A.F, Freeman, Gilbert. 1996. Manajemen, Alih Bahasa Alexander Sindoro. Jakarta: Pt. Prenhallindo.

Syafiie Inu Kencana Dkk. 2001. Hukum Etika Pemerintahan Penerbit : Rineka Cipta:

Yamit, Zulian. 2005. Manajemen Kualitas Produk \& Jasa. Yogyakarta: Ekonisia

Wibowo, 2007. Manajemen Kinerja :Pt Rajg Grafindo Persadap. 